\title{
Combination of aquifer thermal energy storage and enhanced bioremediation: resilience of reductive dechlorination to redox changes
}

\author{
Zhuobiao $\mathrm{Ni}^{1,2} \cdot$ Pauline van Gaans ${ }^{3} \cdot$ Martijn Smit $^{1,4} \cdot$ Huub Rijnaarts ${ }^{1}$. \\ Tim Grotenhuis ${ }^{1}$
}

Received: 12 October 2015 /Revised: 2 December 2015 / Accepted: 7 December 2015 / Published online: 28 December 2015

(C) The Author(s) 2015. This article is published with open access at Springerlink.com

\begin{abstract}
To meet the demand for sustainable energy, aquifer thermal energy storage (ATES) is widely used in the subsurface in urban areas. However, contamination of groundwater, especially with chlorinated volatile organic compounds (CVOCs), is often being encountered. This is commonly seen as an impediment to ATES implementation, although more recently, combining ATES and enhanced bioremediation of CVOCs has been proposed. Issues to be addressed are the high water flow velocities and potential periodic redox fluctuation that accompany ATES. A column study was performed, at a high water flow velocity of $2 \mathrm{~m} / \mathrm{h}$, simulating possible changes in subsurface redox conditions due to ATES operation by serial additions of lactate and nitrate. The impacts of redox changes on reductive dechlorination as well as the microbial response of Dehalococcoides (DHC) were evaluated. The results showed that, upon lactate addition, reductive dechlorination proceeded well and complete dechlorination from cis-DCE to ethene was achieved. Upon subsequent nitrate addition, reductive dechlorination
\end{abstract}

Electronic supplementary material The online version of this article (doi:10.1007/s00253-015-7241-6) contains supplementary material, which is available to authorized users.

Zhuobiao Ni

nizhuobiao@hotmail.com

1 Sub-Department of Environmental Technology, Wageningen University, P.O. Box 17, 6700 AA Wageningen, the Netherlands

2 Wetsus, European Centre of Excellence for Sustainable Water Technology, P.O. Box 1113, 8900 CC Leeuwarden, the Netherlands

3 Soil and Groundwater Systems, Deltares, P.O. Box 85467, 3508 AL Utrecht, the Netherlands

4 Present address: Eurofins Analytico, P.O. Box 459, 3770 AL Barneveld, the Netherlands immediately ceased. Disruption of microorganisms' retention was also immediate and possibly detached DHC which preferred attaching to the soil matrix under biostimulation conditions. Initially, recovery of dechlorination was possible but required bioaugmentation and nutrient amendment in addition to lactate dosing. Repeated interruption of dechlorination and DHC activity by nitrate dosing appeared to be less easily reversible requiring more efforts for regenerating dechlorination. Overall, our results indicate that the microbial resilience of DHC in biosimulated ATES conditions is sensitive to redox fluctuations. Hence, combining ATES with bioremediation requires dedicated operation and monitoring on the aquifer geochemical conditions.

Keywords Reductive dechlorination - Aquifer thermal energy storage (ATES) · cis-dichloroethene (cis-DCE) ·

Dehalococcoides $\cdot$ Microbial resilience $\cdot$ Redox potential $\left(E_{\mathrm{Ag} / \mathrm{AgCl}}\right)$

\section{Introduction}

Aquifer thermal energy storage (ATES) has been developed since the 1970s and is considered as an energy saving and sustainable energy technology (Hendriks et al. 2008; Lee 2013; Novo et al. 2010). The principle of ATES is to store thermal energy when available and retrieve it for use when needed. In summer, groundwater is extracted from ATES cold well. At the heat exchanger, the excessive heat from the building is transported to this water which is then re-injected into the aquifer at the ATES warm well. In the aquifer, a large fraction of heat remains available to be used in winter when the groundwater flow and energy extraction process will be reversed (Lee 2013; Paksoy 2007). Due to an increased demand for sustainable energy, existing ambitions to reduce 
greenhouse gas emission and its cost-effectiveness, ATES is increasingly being developed throughout the world, especially in urban areas (EC 2007; Lee 2010; Snijders 2005; Sommer et al. 2015). For ATES development, Belgium, Germany, the Netherlands, Turkey, Sweden and the USA are currently leading (Andersson et al. 2013; Paksoy et al. 2004; Paksoy et al. 2009; Paksoy 2007; Sanner et al. 2005; Vanhoudt et al. 2011). For example, the number of ATES systems was 2740 in the Netherlands (CBS 2010) and is expected to rise to 20,000 in 2020 (Godschalk and Bakema 2009). Meanwhile, many urban areas are confronted with groundwater contaminations in the aquifer layer, especially with chlorinated solvents (Burston et al. 1993; Lopes and Bender 1998; Moran et al. 2007; Squillace et al. 2002). Chlorinated solvents, in particular, tetrachloroethene (PCE) and trichloroethene (TCE), have been applied widely as degreasers in industrial factories and for dry-cleaning since the 1930s (ITRC 2005; Linn et al. 2004; Longstaff et al. 1992). Due to improper disposal, leakage and accidents, PCE and TCE together with their daughter products cis-dichloroethene (cis-DCE) and vinyl chloride (VC) have become the most prevalent groundwater contaminants in aquifers (Grindstaff 1998; Henry and Warner 2003). These chlorinated volatile organic compounds (CVOCs) are often found at a depth in the subsurface similar to that at which ATES is usually applied (McCarty 2010; Zuurbier et al. 2013). ATES involves the transportation of large volumes of groundwater, for instance 261 million $\mathrm{m}^{3}$ groundwater was displaced by ATES in the Netherlands in 2013(Verburg et al. 2010). Hence, interference between CVOCs and ATES application at the same site can be a threat not only to the quality of groundwater and drinking water but also to human health due to the vapour intrusion especially of the carcinogenic intermediate VC (Picone 2012). Faced with the long duration commonly needed for natural attenuation of CVOCs in the subsurface (ITRC 2008; Wilson et al. 2007) and the increasing demand for ATES, the combination of ATES and stimulated bioremediation might be prosperous to reduce the increasing pressure on the use of the subsurface. The increased temperature around the ATES warm well $\left(20-25^{\circ} \mathrm{C}\right)$ (Slenders et al. 2010; Zuurbier et al. 2013) and using ATES as biostimulation tool, for example, for addition of electron donor, are the two main positive perspectives recognized for such combination (Sommer 2015). Currently, two field scale tests are being performed in the Netherlands where ATES is applied at CVOCs contaminated sites (Lieten et al. 2012; Slenders et al. 2010), which so far have not encountered practical problems. Furthermore, our previous laboratory study under simulated ATES conditions, focusing on cis-DCE biodegradation, showed 13 times higher degradation capacity at increased temperature compared to biodegradation by enhanced natural attenuation at groundwater temperature of $10{ }^{\circ} \mathrm{C}(\mathrm{Ni}$ et al. 2015). These findings are promising; however, the impact on the microbial population is unclear, especially regarding the Dehalococcoides (DHC) species as the only group of bacteria strains capable of completely dechlorinating CVOCs to the harmless product ethene (Aulenta et al. 2006; Ballapragada et al. 1997; Boopathy 2000; Maymó-Gatell et al. 2001; McCarty 1997; van der Zaan et al. 2010).

The displacement of large volumes of groundwater by the ATES system will also have an impact on the local geochemical state of the aquifer. Redox conditions (of groundwater) in natural (undisturbed) aquifers can show a heterogeneous pattern over different depths and lateral positions (Christensen et al. 2000; McMahon and Chapelle 2008). The mixing of large volumes of groundwater, together with temperature changes, may then result in an overall change of redox condition on the re-injected groundwater and thus the aquifer zone around the injection well (Bonte et al. 2013; Jesußek et al. 2013; Possemiers et al. 2014). Because of the seasonal operation of ATES, such change of redox condition can occur in both warm and cold zones. In the worst case, redox change can lead to well clogging by precipitation of iron (hydr)oxides when, for example, dissolved iron encounters nitrates or dissolved oxygen (Brown and Misut 2010; Houben 2006; Kohfahl et al. 2009; Possemiers 2014; van Beek 2011). Also, for microbiological processes in the combination of ATES and bioremediation of CVOCs, the redox potential is a crucial factor, as DHC, which is primarily involved in the reductive dechlorination process, is sensitive to the redox condition (Amos et al. 2008; Maymó-Gatell et al. 2001; Smidt and de Vos 2004; van der Zaan et al. 2010) and especially vulnerable to oxidized redox condition such as nitrate reducing and oxidizing condition (Nobre and Nobre 2004). Exposure to air or oxygen was found to cause irreversible inhibition of reductive dechlorination (Amos et al. 2008). Several studies have revealed that DHC is natively found in many contaminated sites, though often at a very low number (Lendvay et al. 2003; Major et al. 2002). Moreover, DHC is more abundant at contaminated sites with lower redox potential, where reductive dechlorination is actively occurring (Behrens et al. 2008; Lu et al. 2006; Schaefer et al. 2009). Therefore, changing redox condition of groundwater by ATES operation is expected to influence the CVOCs reductive dechlorination by affecting the activity of DHC. Previous studies showed the inhibition effect of nitrate on the dechlorination process of chloroaliphatic (Gerritse et al. 1997; Keith et al. 2005; Mohn and Tiedje 1992; Nelson et al. 2002; Picardal et al. 1995; Ritter et al. 2003; Semprini et al. 1992) and chloroaromatic compounds (Chang et al. 1996; Chen et al. 2002; Genthner et al. 1989; Häggblom et al. 1993; Middeldorp et al. 2005; Milligan and Häggblom 1999; Okutman Tas and Pavlostathis 2008), while only very few studies focused on the responsible microorganism DHC upon its reaction to oxygen (Adrian et al. 2007; Amos et al. 2007; Amos et al. 2008). However, these studies have not covered the situation of possible variation of redox conditions due to 
seasonal operation of ATES. Considering the need of both sustainable energy production and more effective remediation of groundwater contaminants, especially in urban areas, it is wise to investigate the impacts of ATES on bioremediation of these contaminants in advance. Therefore, as the prevalent groundwater contaminants, biodegradation of CVOCs was studied under a simulated ATES condition in this study. We aim to improve the understanding of the resilience of the dechlorinating process by bacteria that are active in contaminated aquifers upon disturbances by redox fluctuation that can be generated by the functioning of an ATES system. We focus on the warm well as we expect that most of the conversion of CVOCs is located at that area. Dynamic redox conditions that might occur in an ATES system were simulated at lab scale by consequent nitrate and lactate additions and were used to determine chemical changes as well as effects on the microbial community and its characteristics.

\section{Materials and methods}

\section{Materials}

Aquifer material from the city of Utrecht, similar as in our previous study (Ni et al. 2014) on PCE biodegradation in a $\mathrm{Fe}$ (III) reducing aquifer, was used. All chemical stock solutions were prepared with anaerobic deionized water, which was purged with pure $\mathrm{N}_{2}$ for at least $3 \mathrm{~h}$. Sodium lactate (SL) stock solution (225 g/L), cis-DCE stock solution $(395 \mathrm{mg} / \mathrm{L})$ and $\mathrm{NaNO}_{3}$ stock solution $(85 \mathrm{~g} / \mathrm{L})$ were prepared, respectively, with SL powder ( $\geq 99 \%$ purity, Aldrich $\left.{ }^{\circledR}\right)$, $\mathrm{NaNO}_{3}$ powder ( $\geq 99 \%$ purity, Aldrich ${ }^{\circledR}$ ) and cis-DCE (99\% anhydrous, Aldrich ${ }^{\circledR}$ ). Anaerobic tap water, prepared similarly as anaerobic deionized water, from the lab was used as liquid medium in the column experiment.

A mixed culture containing 1.3-4.4 $\times 10^{8} \mathrm{DHC}$ cells $/ \mathrm{mL}$ liquid (or DNA copies/mL liquid, based on the assumption that 1 DNA-copy is equal to 1 cell) was provided by Bioclear BV (Groningen, NL). This culture was occasionally fed with cis-DCE and lactate prior to the experiment. Inoculation was performed when cis-DCE and VC were found absent in the headspace of the inoculum bottle.

\section{Analytical methods}

Redox potential and $\mathrm{pH}$ of the experimental systems were monitored by a Consort multi-channel (C3060) metre and data logger with ProSense (QIS) standard Pt redox electrode with $\mathrm{Ag} / \mathrm{AgCl}$ as reference electrode ( $-199 \mathrm{mV}$ vs. standard hydrogen electrode (SHE)) in saturated $\mathrm{KCl}$ solution (Bard and Faulkner 2001) and standard pH electrode (QIS), respectively. Temperature was also monitored and logged by C3060 metre.
Logging interval of redox potential, $\mathrm{pH}$ and temperature was $1 \mathrm{~min}$.

Dissolved $\mathrm{Fe}^{2+}, \mathrm{SO}_{4}{ }^{2-}$, lactate and volatile fatty acids (VFAs) were determined using the same analytical methods as in our previous study with redox titration method on PCE biodegradation in $\mathrm{Fe}$ (III) reducing aquifer (Ni et al. 2014). Biogas was analysed and quantified for $\mathrm{CO}_{2}, \mathrm{CH}_{4}$ and $\mathrm{O}_{2}$ in the headspace on a Shimadzu 2010 GC with thermal conductivity detector (TCD) and with helium as carrier gas. Loop injection of $2 \mathrm{~mL}$ headspace sample was performed at $120{ }^{\circ} \mathrm{C}$. Chlorinated ethene (cis-DCE and VC) and ethene were quantified by direct injection of $100 \mu \mathrm{L}$ (with glass syringe) on a HP6890 series GC equipped with a CP PoraBond $\mathrm{Q}$ column $(25 \mathrm{~m} \times 0.53 \mathrm{~mm} \times 10 \mu \mathrm{m})$ and flame ionization detector (FID). Nitrogen gas was used as carrier gas at a flow rate of $25 \mathrm{~mL} / \mathrm{min}$. The temperature programme started at $60{ }^{\circ} \mathrm{C}$, ramped at $17.78{ }^{\circ} \mathrm{C} / \mathrm{min}$ to $140{ }^{\circ} \mathrm{C}$ and held at $140{ }^{\circ} \mathrm{C}$ for $1.5 \mathrm{~min}$.

Microbial analysis (total bacteria and DHC cell ${ }^{*}$ ) was done by BioClear BV. Before analyses, $5 \mathrm{~mL}$ effluent from the column was collected and stored at $4{ }^{\circ} \mathrm{C}$, in a special storage kit from Bioclear BV.

\section{Recirculating column set-up}

\section{Overview and specification}

The schematic overview and specification of the column setup are given in Fig. 1, Table S1 and Figure S1. The various parts of the column set-up were connected by Teflon tubings ( $\varnothing 4 \mathrm{~mm}$ ) with quick connectors with valves. The aqueous phase was recirculated by a SIMDOS ${ }^{\circledR}$ diaphragm metering pump (flow rate range: $1-100 \mathrm{~mL} / \mathrm{min}$ ). Glass filters (pore size with P2 specification: 100-160 $\mu \mathrm{m}$ ) were placed on the top and bottom of the column to prevent particles from being flushed out. A 150-mL double-side armed bottle with approximately $100-\mathrm{mL}$ headspace volume was placed in the middle of the system for headspace sampling and to prevent underpressure during liquid and headspace sampling.

\section{Preparation and maintenance of column}

All individual parts of the column setup were filled inside an anaerobic hood $\left(95 \% \mathrm{~N}_{2}\right.$ and $\left.5 \% \mathrm{H}_{2}\right)$ with either aquifer material or anaerobic tap water. The buffering bottle was additionally conditioned by exchanging the headspace 10 times with $99 \% \mathrm{~N}_{2}$ and $1 \% \mathrm{CO}_{2}$ gas by an automatic headspace exchanger. The individual parts of the set-up were then attached by the quick connectors and, after opening the valves, the aqueous phase was allowed to circulate at a flow rate of $10 \mathrm{~mL} / \mathrm{min}$. This flow rate is comparable to a groundwater velocity of $2 \mathrm{~m} / \mathrm{h}$, which is a realistic flow velocity in aquifers $1.3 \mathrm{~m}$ away from an ATES well. This ATES system is 


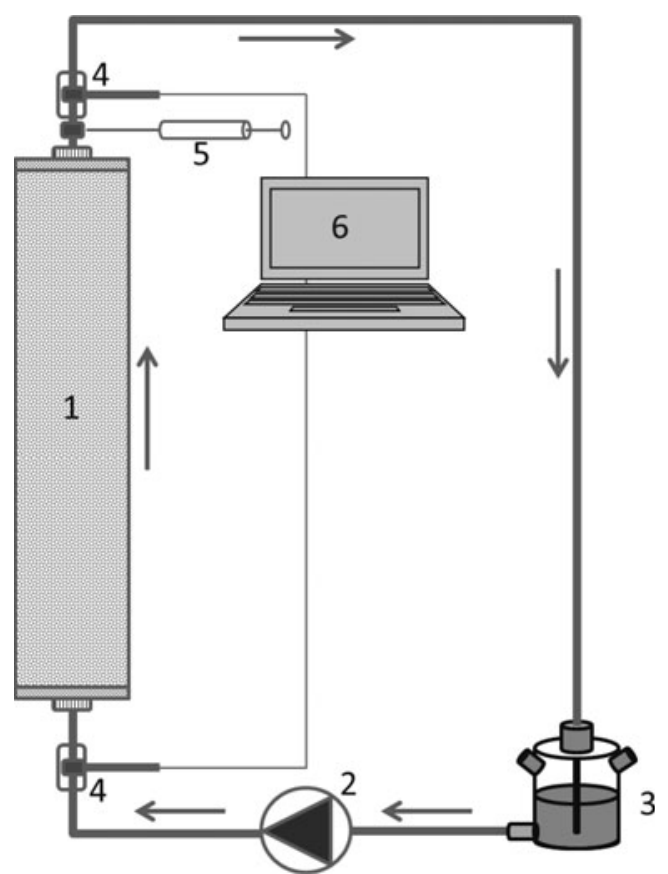

Fig. 1 Schematic diagram of column set-up. 1 aquifer material with glass filters with pore size of $160 \mu \mathrm{m}$ on the top and bottom of the column; 2 membrane pump; 3 buffering bottle; 4 redox and $\mathrm{pH}$ electrodes (bottom is for influent, top is for effluent); 5 liquid sampling port; 6 metre connected with computer. Arrow indicates the direction of water flow

assumed to operate with a flow rate of $100 \mathrm{~m}^{3} / \mathrm{h}$ and with $20 \mathrm{~m}$ filter length (see calculation in Figure S2).

During the first few days, the liquid level in the buffering bottles was lowered due to degassing of the aquifer column and tubing. Extra anaerobic tap water was injected in the bottle to maintain the liquid volume at approximately $50 \mathrm{~mL}$. This procedure to maintain the liquid volume was also carried out later during the experiment, in case more gas bubbles were produced by degassing from the column. Moreover, after every liquid sampling, the same amount of anaerobic tap water as liquid sample was injected.

During the whole experimental period, small but continuous diffusion of oxygen was occurring, resulting in a volume concentration of about $1 \%$ in the headspace of the buffering bottle. By lactate additions (Table 1) the redox condition in the columns was always kept anaerobic as can be observed from the redox measurements at the inflow and outflow of the sediment column. Besides, some continuous removal of cis-DCE, $\mathrm{VC}$ and ethene from the column was also observed, most probably due to diffusion through the Teflon tubing (Parker et al. 1990; Rowe et al. 1995). Parker et al. (1990) showed a more than $10 \%$ loss of chlorinated organic in the stored sampling with Teflon material after $8 \mathrm{~h}$. Therefore, a continuous dissipation of CVOCs was observed; however, the formation and development trend of these compounds could still well be observed to determine biodegradation of cis-DCE and reflect the DHC resilience. The used tubing was the best to our knowledge among the available material that could be used in this experiment.

\section{Experimental procedures}

Dynamic redox conditions were simulated by adding lactate as electron donor to achieve lower redox potential or by adding nitrate as electron acceptor to raise the redox potential. In total, two cycles of low and elevated redox potential were performed. During the experiment, liquid was sampled at position 5 in Fig. 1, while headspace sampling was done at the side arms of the buffering bottle. Addition of chemicals was also done via these side arms. The experiment lasted for 140 days with in total of 28 actions which are listed in Table 1.

Important procedures included (1) monitoring initial behaviour of selected aquifer material in the column system in the adaptation period of 20 days; (2) redox conditioning by adding lactate as electron donor to achieve an environmental condition with redox potential around $-450 \mathrm{mV}$ to stimulate reductive dechlorination (Ni et al. 2014). For this purpose, three lactate additions on day 20, 66 and 114 were performed with 1.5, 1 and $1 \mathrm{~mL}$ lactate stock, respectively (Table 1). Additional lactate additions of $0.5 \mathrm{~mL}$ lactate stock on day $45,55,71,84,92,98,101,104$ and 134 were to maintain the low redox potential that is suitable for DHC. The addition of electron donor was found to be necessary as the redox potential slowly increased, due to the continuous diffusion of $\mathrm{O}_{2}$ through the Teflon tubing; (3) inoculating the column system with DHC in the period without any chlorinated ethenes present to study the distribution of DHC in the model ATES system (day 30), the subsequent DHC inoculations on day 41, 80, 93, 125 and 132 (Table 1) were performed to startup or to recover the reductive dechlorination; (4) spiking of cis-DCE stock. In total, 9 times of cis-DCE spiking with $5 \mathrm{~mL}$ cis-DCE stock for each; approximately $20 \mu \mathrm{mol}$ cis-DCE/ spiking (Table 1) were conducted on day 41, 48, 51, 56, 62, 76, 91, 98 and 104; (5) two times nitrate stock additions $(5 \mathrm{~mL}$ for each) as redox shock to bring up the redox potential on day 57 and 105; (6) addition of $2.5 \mathrm{~mL}$ of nutrient solution containing $50 \mathrm{~g} / \mathrm{L} \mathrm{Na}_{2} \mathrm{HPO}_{4}, 50 \mathrm{~g} / \mathrm{L} \mathrm{KH}_{2} \mathrm{PO}_{4}$ and $10 \mathrm{~g} / \mathrm{L} \mathrm{NH}_{4} \mathrm{Cl}$ ), $2.5 \mathrm{~mL}$ of $10 \mathrm{~g} / \mathrm{L} \mathrm{NH}_{4} \mathrm{Cl}$ and $5 \mathrm{~mL}$ vitamin $\mathrm{B}_{12}$ medium on day 94,118 and 135 for promoting the recovery of reductive dechlorination.

\section{Results}

\section{Redox potential and other redox indicators}

During the first 20 days, the redox potential in the column was monitored without any redox conditioning steps. After an initial stabilization at $-100 \mathrm{mV}$, the redox potential rapidly dropped to $-350 \mathrm{mV}$ on day 4 and further to $-450 \mathrm{mV}$ on 
Table 1 Overview of actions and related additions of different chemicals

\begin{tabular}{|c|c|c|c|c|c|c|}
\hline \multirow[t]{2}{*}{ Action } & \multirow[t]{2}{*}{ Day } & \multicolumn{5}{|l|}{ Addition of } \\
\hline & & Lactate $(225 \mathrm{~g} / \mathrm{L})$ & Inoculum (5 mL) & $\begin{array}{l}\text { cis-DCE }(5 \mathrm{~mL} \\
395 \mathrm{mg} / \mathrm{L})\end{array}$ & $\begin{array}{l}\mathrm{NaNO}_{3}(5 \mathrm{~mL} \\
85 \mathrm{mg} / \mathrm{L})\end{array}$ & Other \\
\hline 1 & 20 & $1.5 \mathrm{~mL}$ & & & & \\
\hline 2 & 30 & & $1.3 \times 10^{8}$ cells $/ \mathrm{mL}$ & & & \\
\hline 3 & 41 & & $3.2 \times 10^{8}$ cells $/ \mathrm{mL}$ & $\mathrm{x}$ & & \\
\hline 4 & 45 & $0.5 \mathrm{~mL}$ & & & & \\
\hline 5 & 48 & & & $\mathrm{x}$ & & \\
\hline 6 & 51 & & & $\mathrm{x}$ & & \\
\hline 7 & 55 & $0.5 \mathrm{~mL}$ & & & & \\
\hline 8 & 56 & & & $\mathrm{x}$ & & \\
\hline 9 & 57 & & & & $\mathrm{x}$ & \\
\hline 10 & 62 & & & $\mathrm{x}$ & & \\
\hline 11 & 66 & $1 \mathrm{~mL}$ & & & & \\
\hline 12 & 71 & $0.5 \mathrm{~mL}$ & & & & \\
\hline 13 & 76 & & & $\mathrm{x}$ & & \\
\hline 14 & 80 & & $2.5 \times 10^{8}$ cells $/ \mathrm{mL}$ & & & \\
\hline 15 & 84 & $0.5 \mathrm{~mL}$ & & & & \\
\hline 16 & 91 & & & $\mathrm{x}$ & & \\
\hline 17 & 92 & $0.5 \mathrm{~mL}$ & & & & \\
\hline 18 & 93 & & $2.9 \times 10^{8}$ cells $/ \mathrm{mL}$ & & & \\
\hline 19 & 94 & & & & & $\begin{array}{l}\text { Nutrient }\left(2.5 \mathrm{~mL} ; \mathrm{Na}_{2} \mathrm{HPO}_{4}\right. \\
50 \mathrm{~g} / \mathrm{L}, \mathrm{KH}_{2} \mathrm{PO}_{4} 50 \mathrm{~g} / \mathrm{L}, \\
\left.\mathrm{NH}_{4} \mathrm{Cl} 10 \mathrm{~g} / \mathrm{L}\right)\end{array}$ \\
\hline 20 & 98 & $0.5 \mathrm{~mL}$ & & $\mathrm{x}$ & & \\
\hline 21 & 101 & $0.5 \mathrm{~mL}$ & & & & \\
\hline 22 & 104 & $0.5 \mathrm{~mL}$ & & $\mathrm{x}$ & & \\
\hline 23 & 105 & & & & $\mathrm{x}$ & \\
\hline 24 & 114 & $1 \mathrm{~mL}$ & & & & \\
\hline 25 & 118 & & & & & $\mathrm{NH}_{4} \mathrm{Cl}(2.5 \mathrm{~mL} ; 10 \mathrm{~g} / \mathrm{L})$ \\
\hline 26 & 125 & & $3.6 \times 10^{8}$ cells $/ \mathrm{mL}$ & & & \\
\hline 27 & 132 & & $4.4 \times 10^{8}$ cells $/ \mathrm{mL}$ & & & \\
\hline 28 & 134 & $0.5 \mathrm{~mL}$ & & & & \\
\hline 29 & 135 & & & & & $\begin{array}{l}\text { Vitamin } \mathrm{B}_{12} \text { medium } \\
\quad(5 \mathrm{~mL} ; 2 \mathrm{mg} / \mathrm{L})\end{array}$ \\
\hline
\end{tabular}

day 6 (Fig. 2). Thereafter, starting at day 12, the redox potential increased up to about $150 \mathrm{mV}$ on day 20 , ascribed to oxygen diffusion through the Teflon tubing.

After addition of lactate (action, day 20), the redox potential in both influent and effluent decreased to $-450 \mathrm{mV}$ and remained stable at this low value. This low redox potential is reported to be suitable for reductive dechlorination and methanogenesis (Christensen et al. 2000; ITRC 2005; Ni et al. 2014). The nitrate addition on (action 9, day 57) resulted in an increase of redox potentials up to $-150 \mathrm{mV}$ within 2 days and continued to increase to $107 \mathrm{mV}$ in the influent and $25 \mathrm{mV}$ in the effluent during the following 8 days (Fig. 2). The subsequent lowering of the redox potential was initiated by the addition of lactate on day 66 (action 11). Similar to the first lactate addition, the redox potential dropped sharply to below $-400 \mathrm{mV}$ within 1 day and remained stable until day 105 when the second nitrate addition was performed (action 23). After this second nitrate addition, the redox potential increased up to $-70 \mathrm{mV}$, which was around $170 \mathrm{mV}$ below the value reached upon the first nitrate addition. Low redox potentials (from -400 to $-500 \mathrm{mV}$ ) were again obtained after the third addition of lactate on day 114 (action 24). Interestingly, the redox potential showed less noise after this lactate addition compared to earlier additions of lactate (Fig. 2, after action 24).

Prior to any addition of lactate, acetate was detected with a maximum concentration of $0.27 \mathrm{mmol} / \mathrm{L}$ on day 7 and was consumed before the first lactate addition on day 20 . 
Fig. 2 Redox potential of the influent (blue line) and the effluent (red line). Black arrows and with numbers indicate different actions listed in Table 1

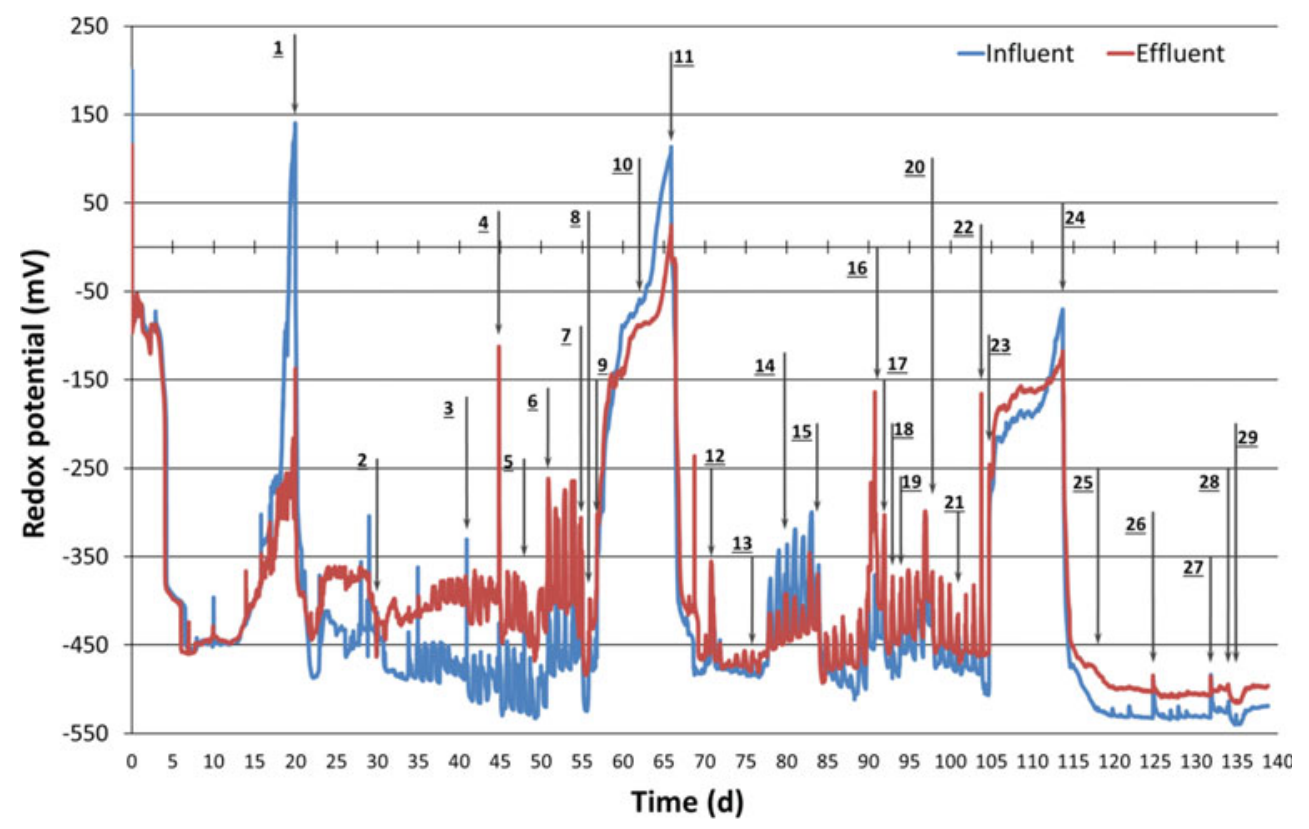

Propionate was not detected at this stage. After the first addition of lactate, the concentration of acetate increased rapidly to $8.55 \mathrm{mmol} / \mathrm{L}$, while the concentration of propionate increased to $2.43 \mathrm{mmol} / \mathrm{L}$ (Fig. 3a). The concentration of these two volatile fatty acids (VFAs) followed a pattern of rapid increase and gradual decrease with every lactate addition. After nitrate additions (action 9, day 57 and action 23, day 105), the decrease of VFA concentration was fast, however. Lactate was not detected along the experiment indicating that the production of acetate and propionate resulted from a fast process such as lactate fermentation (Ni et al. 2014; Seeliger et al. 2002).
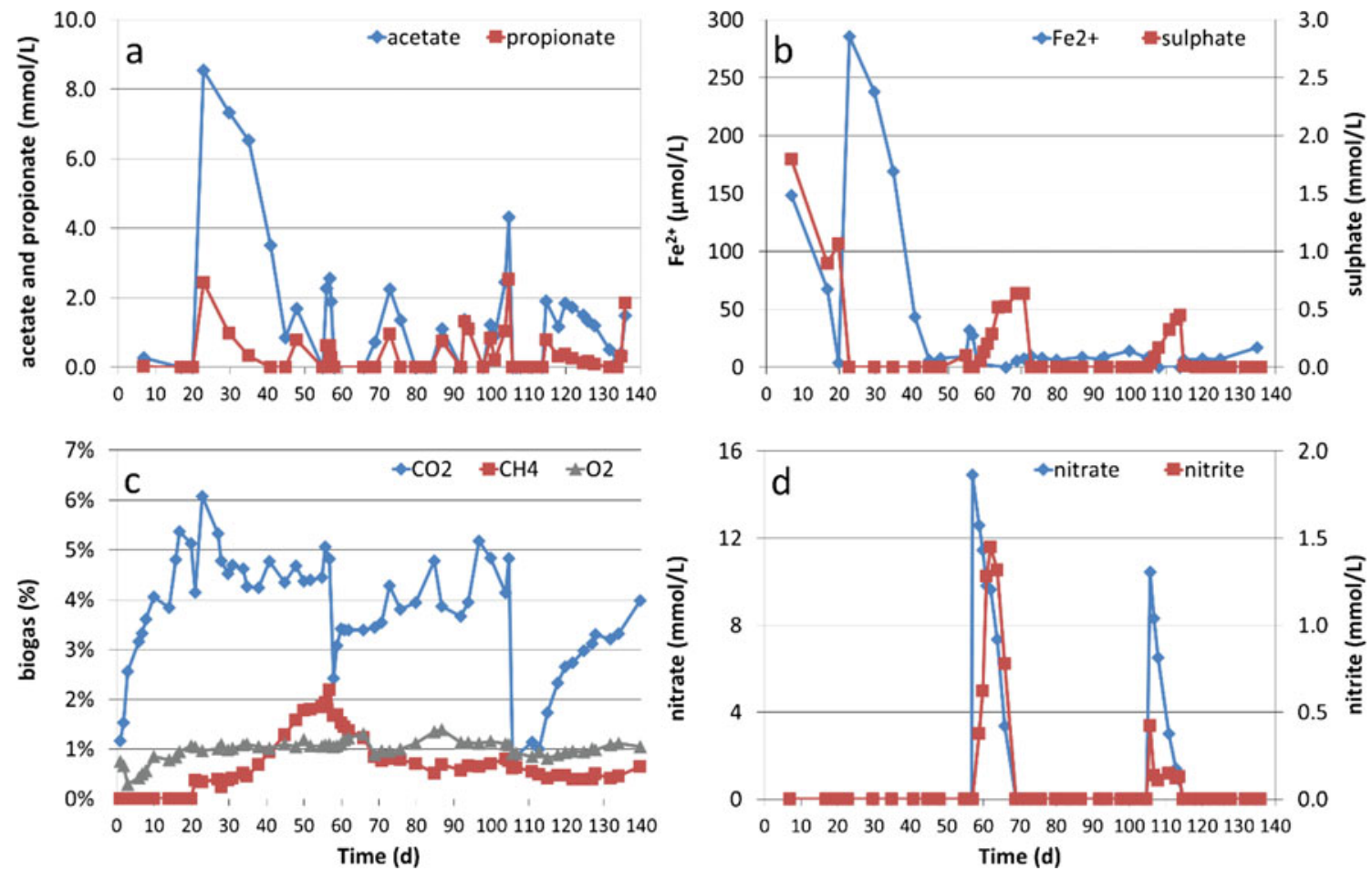

Fig. 3 Concentrations of different compounds as a function of experimental time. a (top left) represents acetate and propionate concentration with unit of $\mathrm{mmol} / \mathrm{L}$ in liquid sampling port; $\mathbf{b}$ (top right) represents $\mathrm{Fe}^{2+}$ (primary $y$-axis) and sulphate (secondary $y$-axis) concentration with unit of $\mu \mathrm{mol} / \mathrm{L}$ and $\mathrm{mmol} / \mathrm{L}$, respectively, in liquid

sampling port; c (bottom left) represents $\mathrm{O}_{2}, \mathrm{CH}_{4}$ and $\mathrm{CO}_{2}$ gas composition in the headspace of the buffering bottle in percentage; $\mathbf{d}$ (bottom right) represents nitrate (primary $y$-axis) and nitrite (secondary $y$-axis) concentration with unit of $\mathrm{mmol} / \mathrm{L}$ in liquid sampling port 
The initial concentration of $\mathrm{Fe}^{2+}$ in the aqueous phase was close to $148 \mu \mathrm{mol} / \mathrm{L}$ and decreased to below $4 \mu \mathrm{mol} / \mathrm{L}$ during the 3 weeks prior to the first addition of lactate (Fig. 3b). The first addition of lactate lead to a large increase of $\mathrm{Fe}^{2+}$ concentration up to $286 \mu \mathrm{mol} / \mathrm{L}$ on day 23 whereafter the concentration returned to low values $(0-20 \mu \mathrm{mol} / \mathrm{L})$. Subsequent additions of lactate did not result in elevated $\mathrm{Fe}^{2+}$ concentrations (Fig. 3b). Sulphate concentration, $(1.8 \mathrm{mmol} / \mathrm{L}$ at the start), decreased steadily to about $1.0 \mathrm{mmol} / \mathrm{L}$ during the first 20 days. Thereafter, the sulphate concentration declined quickly to negligible zero with first lactate addition (action 1 , day 20). Only after nitrate addition (action 9, day 57; action 23, day105), elevated sulphate concentrations were observed (Fig. 3b).

Biogas analysis showed that the concentration of $\mathrm{CO}_{2}$ increased immediately at the start of the experiment and the percentage reached a highest value of around $6 \%$ on day 23 (Fig. 3c). In the two periods when nitrate was added (action 9, day 57; action 23, day 105), the $\mathrm{CO}_{2}$ percentage rapidly decreased to about 2 and $1 \%$, respectively. After subsequent lactate addition (action 11, day 66; 24, day 114), the $\mathrm{CO}_{2}$ gradually returned to values around $4 \%$, with some fluctuations in the rest of periods (Fig. 3c). $\mathrm{CH}_{4}$ was detected after the first lactate addition (action 1, day 20). The highest $\mathrm{CH}_{4}$ concentration was observed right before nitrate addition on day 57 (around $2 \%$ ). After the second nitrate addition, the concentration slowly declined to less than $1 \%$ and further below $0.5 \%$. The $\mathrm{O}_{2}$ percentage in the headspace of the buffering bottle was stable at about $1 \%$ during the experiment (Fig. 3c).

Neither nitrate nor nitrate was detected before nitrate addition on day 57 . Nitrate concentration peaked at $15.0 \mathrm{mmol} / \mathrm{L}$ on day 58 , after which the production of nitrite occurred with a maximum concentration of $1.45 \mathrm{mmol} / \mathrm{L}$ (Fig. 3d). After lactate addition (action 11, day 66), nitrate and nitrate concentrations rapidly decreased to below detection limits on day 69. A similar pattern was observed after the second nitrate addition although the peak concentrations for both nitrate $(10.5 \mathrm{mmol} /$ $\mathrm{L})$ and nitrite $(0.4 \mathrm{mmol} / \mathrm{L})$ were lower than those in the first time. The nitrite peak was smaller and occurred simultaneously with nitrate, indicating the presence of adapted nitrate and nitrite reducing microbial community and thus faster denitrification process.

\section{Reductive dechlorination and microbial population}

First cis-DCE was spiked on day 41 (action 3) when the column remained at stable conditions regarding the redox indicators. Readily after spiking with cis-DCE, the presence of VC and ethene was observed, indicating that the complete pathway of reductive dechlorination is occurring (Fig. 4). When the redox went up to $-250 \mathrm{mV}$ unexpectedly, the production of $\mathrm{VC}$ and ethene ceased (day 52). However, after the lactate addition on day 55 (action 7), the production of these compounds resumed and reached 24.6 and $11.8 \mu \mathrm{mol}$ for $\mathrm{VC}$ and ethene, respectively.

After the first nitrate addition (action 9, day 57), the production of $\mathrm{VC}$ and ethene stopped, although all three compounds disappeared with comparable rates from the reactor (Fig. 4), most probably due to diffusion via the via the Teflon tubing. Restoring the redox potential to its previous low values by the addition of lactate (action 11, day 66 and action 12, day 71) did not result in any noticeable recovery of reductive dechlorination. Even after adding fresh DHC (action14, day 80), two additions of lactate (action 15, day 84, action17, day 92), followed by DHC inoculum (action18, day 93 (DHC), dechlorination did not resume. Only after adding nutrients (action 19, day 94), the production of VC and ethene observably increased, which was further enhanced upon an extra addition of cis-DCE and lactate (action 20, day 98).

The second addition of nitrate (action 23, day 105) aimed at a repetition to test the resilience of reductive dechlorination after a redox shock. This time, reductive dechlorination as evidenced by production of $\mathrm{VC}$ and ethene, did not resume after addition of lactate (action 24, day 114), nutrients (action 25, day 118), and two DHC inoculum (action 26, day 125, action 27, day 132), again lactate addition (action 28, day 134) and finally addition of vitamin $\mathrm{B}_{12}$ (action 29, day 135).

The presence of DHC in the liquid phase followed with time is presented in Fig. 5, as well as the concentration of the total bacteria in the liquid phase. During the first 30 days, DHC concentration was below detection limit. Readily after inoculation with $5 \mathrm{~mL}$ DHC $\left(1.3 \times 10^{8}\right.$ cells $\left./ \mathrm{mL}\right)$, the DHC could be detected in liquid but below the quantification limit (red diamond on day 40 in Fig. 5).

After cis-DCE was spiked and reductive dechlorination occurred (day 40-56), the DHC concentration increased to $5.6 \times 10^{4}$ cells $/ \mathrm{mL}$, which was about $2 \%$ of the total bacteria concentration in the liquid phase. Interestingly, an increased concentration of DHC $\left(3.1 \times 10^{5}\right.$ cells $\left./ \mathrm{mL}\right)$ was detected in the liquid only 2 days after nitrate addition, while reductive dechlorination had ceased. Shortly after this increase, the concentration of DHC diminished to below detection limit in the next analysis on day 66 (Fig. 5) and remained at this low concentration even after a new inoculation (action 14, day 80).

After a second inoculation (action 18, day 93) and the addition of nutrients (action 19, day 94), reductive dechlorination resumed and DHC concentration increased to $6.9 \times 10^{4}$ cells $/ \mathrm{mL}$, which was quantifiable though low compared to the amount of total bacteria $\left(1.7 \times 10^{8}\right.$ cells $\left./ \mathrm{mL}\right)$.

The second nitrate addition showed that the DHC concentration gradually declined to $5 \times 10^{3}$ cells $/ \mathrm{mL}$ after 10 days (Fig. 5) (action 23, day 105). Aiming to resume the reductive dechlorination, DHC was inoculated twice (action 26, day 125, action 27 , day 132) resulting in a DHC concentration of $3.5 \times 10^{4}$ cells/ $\mathrm{mL}$ in the liquid, at the end of experiment. However, reductive 
Fig. 4 Concentration of cis-DCE (blue diamond), $\mathrm{VC}$ (red square) and ethene (grey triangle) as a function of experimental time. Black arrows and with numbers indicate different actions listed in Table 1

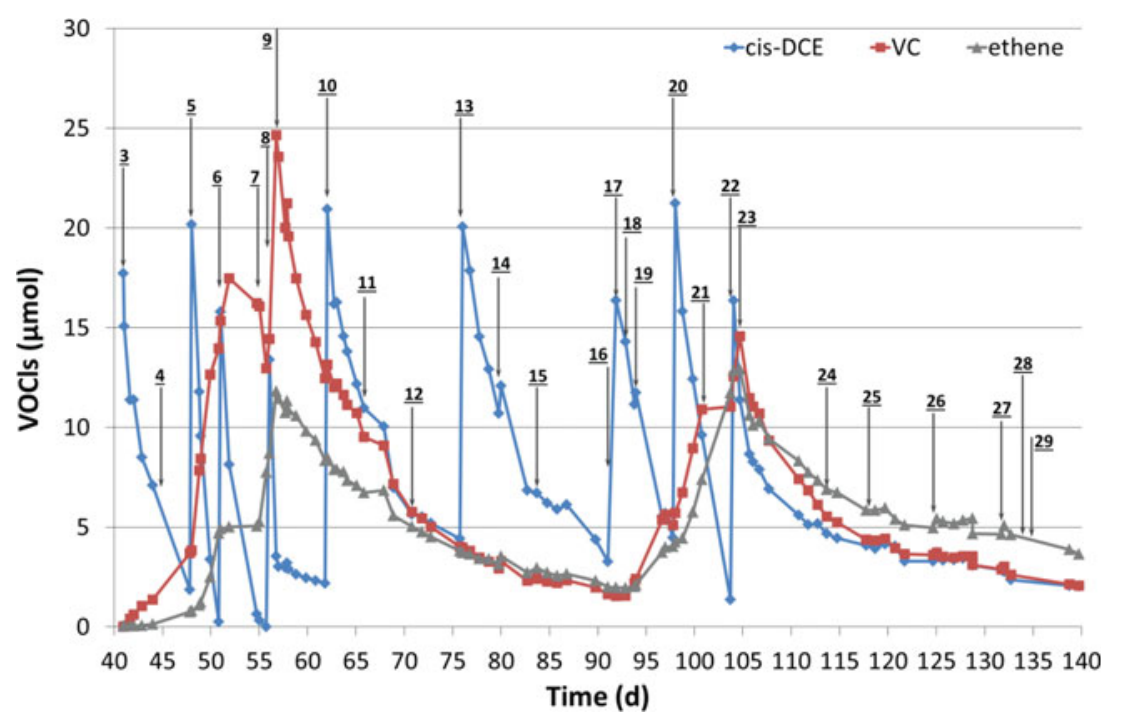

dechlorination, as evidenced by an increase in ethene, did not resume.

The total bacteria concentration in the liquid phase with initial concentration of $2.8 \times 10^{5}$ cells $/ \mathrm{mL}$ significantly expanded during the experiment. The maximum expansion reached four orders of magnitude on day 107 with concentration of $3.2 \times 10^{9}$ cells $/ \mathrm{mL}$, despite the final concentration reduced to $2.5 \times 10^{7}$ cells $/ \mathrm{mL}$. A variety of microbiological processes might be stimulated by this bacterial community, as was reflected by the responses upon redox chemistry and bioprocess indicators presented in Fig. 3.
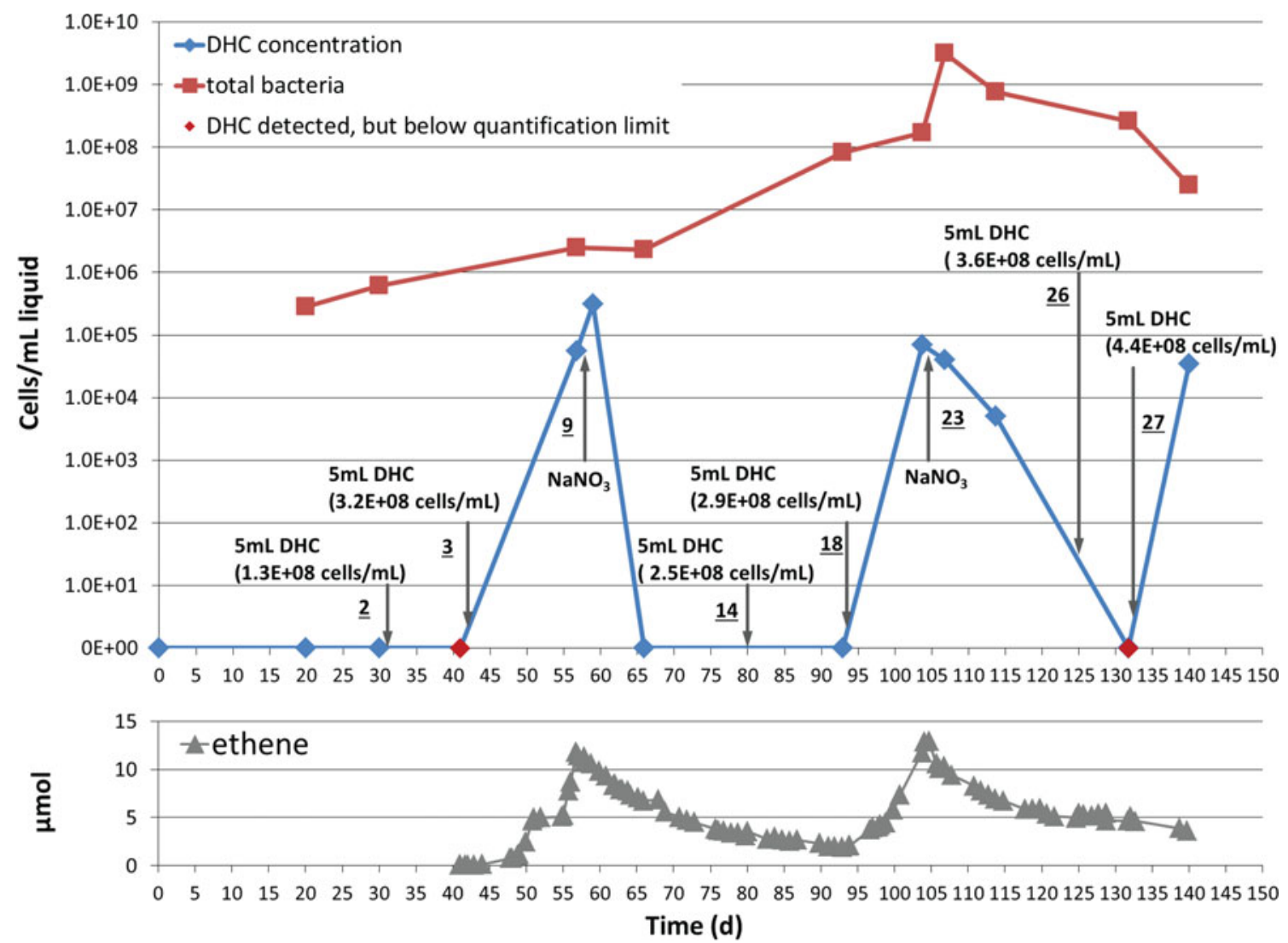

Fig. 5 Change of DHC (blue or red diamond) and total bacteria (red square) concentrations in the liquid phase along time and with comparison to the change of ethene concentration (grey triangle) during the experiment. Black arrows indicate either addition of active DHC inoculum (action 2, 3, 14, 18, 26 and 27) or nitrate (action 9 and 23) 


\section{Discussion}

\section{Redox parameters}

After the start of the experiment, the redox potential in both inflow and outflow showed a rapid lowering down to $-380 \mathrm{mV}$ at day 4 , followed by a period of gradual decrease down to $-400 \mathrm{mV}$ at day 6 and again a rapid decrease down to $-450 \mathrm{mV}$ at day 7. Most probably, organic matter is produced in this phase which released by packing of the column and by organic particles that are disrupted by shear forces at the high liquid flow velocity (Wu et al. 2009). The released organic matter can function as electron donor for biodegradation as we observed in a batch experiment with the same aquifer material at intensive shaking condition (Figure S3). The period of gradual decreasing redox potential between day 4 and 6 probably gave onset to the reduction of readily available $\mathrm{Fe}^{3+}$ species to dissolved $\mathrm{Fe}^{2+}$, as evidenced by the remaining $\mathrm{Fe}^{2+}$ concentration measured at day 7 .

The net removal of $\mathrm{Fe}^{2+}$ from the liquid phase together with sulphate points towards continued reduction of both iron and sulphate and subsequent precipitation as iron sulphides between day 7 and day 17. Then, however, the gradual increase in redox potential due to the oxygen diffusion inverted these processes as, between day 18 and 20, sulphate partly re-dissolved. The on-going removal of $\mathrm{Fe}^{2+}$ from the liquid phase implies that during this period also $\mathrm{Fe}^{2+}$ being oxidized and precipitated as iron (hydr)oxides again. With the first lactate addition at day 20 , the remaining sulphate was rapidly reduced to sulphide (Fig. 3b). The rapid increase in $\mathrm{Fe}^{2+}$ after this first lactate addition, when no DCE had yet been added to the system, seems to be related to the concurrent high acetate concentration (Fig. 3a), which suggests increased iron solubility due to Fe-acetate complexation (Theis and Singer 1974). Thereafter, the $\mathrm{Fe}^{2+}$ concentration was always below $30 \mu \mathrm{mol} /$ $\mathrm{L}$, which can be caused by precipitation with sulphide again or carbonate, leading to formation of $\mathrm{Fes}$ and $\mathrm{FeCO}_{3}$ with negligible solubility (Bénézeth et al. 2009; Davison 1980).

After 12 days, the readily available organic matter seemed to be depleted and could not donate electrons to sufficiently compensate the inflow of oxygen that was presumed to diffuse through the Teflon tubing into the system (Giacobbe 1992; Peirce 1958). This is supported by the observation that the redox potential of the inflow is continuously higher than the redox potential of the outflow. By addition of lactate, the effect of oxygen diffusion on the redox potential was negligible and a stable low redox potential was obtained.

After the nitrate additions (action 9, day 57 and action 23, day 105), the redox potential elevated to 100 and $-70 \mathrm{mV}$, respectively (Fig. 2). This increase resulted in a temporary increase of sulphate, as sulphide oxidation was occurring coupled with nitrate as terminal electron acceptor (Aminuddin and Nicholas 1973; Brunet and Garcia-Gil
1996). In these nitrate reducing periods, $\mathrm{Fe}^{2+}$ as electron donor was also oxidized by nitrate leading to no detectable concentration in the dissolved phase (Straub et al. 1996). The nitrate is then reduced to nitrite by lactate or VFAs (Fig. 3d) which is consistent with other studies (Elefsiniotis et al. 2004; Fass et al. 1994).

The build-up of both $\mathrm{CO}_{2}$ and $\mathrm{CH}_{4}$ in the gas phase, especially in the first period of biostimulation, is the evidence of methanogenic redox conditions being achieved. The sudden decrease in $\mathrm{CO}_{2}$ concentration in the headspace upon nitrate addition was attributed to the fast consumption of protons and electrons in the system for nitrate reduction (Guerrero et al. 1981; Postma et al. 1991). The consumption of protons led to a clear increase in $\mathrm{pH}$ level up to 7.6 and 8.0 (Figure S4, influent), resulting in of the uptake of $\mathrm{CO}_{2}(\mathrm{~g})$ into $\mathrm{HCO}_{3}{ }^{-}$ (aq) (Stirling 2011). The decrease of methane concentration upon nitrate addition is attributed to the inhibition of methanogenesis by nitrate and diffusion of methane through the Teflon tubing (Božic et al. 2009; Roy and Conrad 1999).

In summary, the behaviour of redox potential properly reflected other microbiological processes, such as fermentation, $\mathrm{Fe}(\mathrm{III})$ and sulphate reduction, methanogenesis and denitrification. These processes are considered to be important indications on reductive dechlorination (Aulenta et al. 2006; Boopathy 2000; ITRC 2008; Nelson et al. 2002). Therefore, monitoring redox potential in the groundwater is of importance to evaluate the potential and the progress of reductive dechlorination in the subsurface (Ni et al. 2014).

\section{Resilience of Dehalococcoides and robustness of the reductive dechlorination process upon redox changes}

At the start of the experiment, DHC was not detected which was expected as CVOCs were absent in the original samples and the redox conditions were unfavourable for reductive dechlorination (Kouznetsova et al. 2010; McCarty 1997; Ni et al. 2014; van der Zaan et al. 2010). The absence of DHC in the original sample is furthermore supported by Cupples et al. (2004) who stated that the decay rate of DHC increases if the concentration of cis-DCE and VC as electron acceptor is less than $0.7 \mu \mathrm{mol}$. Only after inoculation with $5 \mathrm{~mL}$ inoculum of around $10^{8}$ cells $/ \mathrm{mL}$, DHC could be detected, although at a low level. This indicates that if all or most DHC was suspended, its concentration should have been detected as about $10^{6}$ to $10^{7}$ cells $/ \mathrm{mL}$, based on the total liquid volume (approximately $250 \mathrm{~mL}$ ) within the column. In fact, during the whole experiment, the observed DHC concentration by sampling from the liquid phase was virtually negligible compared to the DHC that was inoculated. Even the quantifiable measurements observed in periods of active dechlorination showed that DHC concentrations were still less than $0.1 \%$ of the previously added amount, indicating that large part of 
DHC is preferentially attached to the soil matrix. This finding is consistent with other studies which show DHC are less planktonic and mostly favour to attach to soil (Amos et al. 2009; Behrens et al. 2008). Besides, Doong et al. (1997) showed the performance of dechlorinating bacteria is 2 to 5 times better with attachment to porous medium. Furthermore, growth of DHC could be expected in the two active periods of reductive dechlorination (Cupples et al. 2003; He et al. 2003; Scheutz et al. 2008), which could be the reason that quantifiable DHC were detected in the liquid phase on day 56 and 104. The small (one order of magnitude) increase in DHC concentration between day 57 and 59, with the subsequent measurement below detection, could be due to interruption by nitrate of DHC activity, leading to its detachment and transfer to the liquid phase with DHC dying off eventually. The balance between the rate of DHC detachment and DHC decay after the second nitrate dose seems slightly different. Interestingly, the final analysis showed a quantifiable DHC concentration in the liquid but without observable dechlorination proceeding. An explanation may be cis-DCE concentration, which was below $5 \mu \mathrm{mol}$ after day 115 (Fig. 4), was too low for DHC to metabolize or even survive, leading to some persisting inoculated cells to be observed in the liquid.

The inhibition of nitrate on reductive dechlorination found in this study upon nitrate addition was in line with previous research (Nelson et al. 2002; Ritter et al. 2003; Schlicker et al. 2000). After the first nitrate shock, the reductive dechlorination process could be restarted, but only by adding new DHC and nutrients. After the second nitrate shock, no restart of the dechlorination process at any significant rate could be observed. Irreversible inhibition of dechlorination by elevated redox potential has been reported by several studies (Amos et al. 2008; Doğan-Subaş1 et al. 2013; Nelson et al. 2002). Yet, recovery of reductive dechlorination after applying chemical oxidation by permanganate and persulphate followed by bioaugmentation in laboratory experiments has also been described (Doğan-Subaş1 et al. 2013; Hrapovic et al. 2005; Sahl et al. 2007). In a field test, recovery was even reported to occur without bioaugmentation but ascribed to inflow of groundwater and recolonisation by microorganisms from unaffected zones (Sutton et al. 2015). Although these studies are confronted with lag periods of up to hundreds of days, recovery of reductive dechlorination is proven with amendments which were mainly attributed to bioaugmentation. In contrast, our column was much less robust, even after several amendments including sufficient electron donor, nutrient, bioaugmentation and vitamin $B_{12}$ which are beneficial to either DHC growth or reductive dechlorination (He et al. 2007; Hu et al. 2013; ITRC 2005; Miura et al. 2015; Reinhold et al. 2012). One reason could be the much higher flow rates in our experiment compared to other column systems (Hrapovic et al. 2005; Sahl et al. 2007). Another explanation could be that the diffusion rate of cis-DCE, VC and ethene overcame the dechlorination rate, concealing any ongoing dechlorination process from being observed. The last cis-DCE spiking was performed on day 104 and its concentration had dropped to below $5 \mu \mathrm{mol}$ after 10 days (Fig. 4). Such low cisDCE concentration might be insufficient to show measurable conversion into $\mathrm{VC}$ or ethene by $\mathrm{DHC}$, while diffusion was always proceeding.

\section{Implications for combining CVOCs bioremediation and ATES}

In this novel study, we fundamentally investigated the impact of ATES on enhanced CVOCs bioremediation by addressing many important microbiological processes that occur in both systems. The findings are relevant and meaningful to the combination of ATES and enhanced bioremediation. Our results show that reductive dechlorination is sensitive to increased redox potentials. Therefore, proper operation of ATES is recommended avoiding the mixing of oxidized groundwater into more reduced aquifers. Such an approach is already in practise for iron rich groundwater, as iron precipitates and therefore clogging will occur with oxygenated water. The heterogeneity of the subsurface would also provide some protection of microorganisms against negative disturbances, for example, by providing stabile redox micro niches in the subsurface. Hence, the risk of interruption of dehalogenation by oxidized water in practise is expected to be less than that is shown in our study. Further, it was shown that at the mimicked ATES conditions, active dehalogenating DHC cells appear to be preferentially attached to the soil matrix, instead of being mobile and transported with the water phase. Hence, for the combination ATES and bioremediation of CVOCs, bioaugmentation by injecting mobile DHC will profit from this behaviour, as it can be expected that DHC augmentation will lead to attachment to the soil matrix after injection. From our experiment it is expected that inoculation with DHC in the warm well creates optimal conditions in the warm ATES well for reductive dechlorination at high biomass concentrations and at elevated temperature. These results show that practical application of the combination of ATES and in situ dehalogenation technologies can be promising by proper engineering, initial characterization, continued monitoring of the groundwater systems and well-designed bioaugmentation procedures.

Acknowledgments This work was performed in the cooperation framework of Wetsus, European Centre of Excellence for Sustainable Water technology (www.wetsus.eu). Wetsus is co-funded by the Dutch Ministry of Economic Affairs and Ministry of Infrastructure and Environment, the Province of Fryslân and the Northern Netherlands Provinces. The authors would like to thank the participant of the research theme "Underground water functions and well management" for the fruitful discussions and their financial support. We are also thankful for the financial support from Deltares and Brabant Water and acknowledge Bioclear for the supply of inoculum, help in microbial analysis and sampling of aquifer material. 


\section{Compliance with ethical standards}

Ethical statement This manuscript is in compliance with Ethical Standards. This manuscript does not contain any studies with human participants or animals performed by any of the authors.

Conflict of interest All authors declare that they have no interests.

Open Access This article is distributed under the terms of the Creative Commons Attribution 4.0 International License (http:// creativecommons.org/licenses/by/4.0/), which permits unrestricted use, distribution, and reproduction in any medium, provided you give appropriate credit to the original author(s) and the source, provide a link to the Creative Commons license, and indicate if changes were made.

\section{References}

Adrian L, Hansen SK, Fung JM, Görisch H, Zinder SH (2007) Growth of Dehalococcoides strains with chlorophenols as electron acceptors. Environmental Science \& Technology 41(7):2318-2323. doi:10. $1021 / \mathrm{es} 062076 \mathrm{~m}$

Aminuddin M, Nicholas DJD (1973) Sulphide oxidation linked to the reduction of nitrate and nitrite in Thiobacillus denitrificans. Biochimica et Biophysica Acta (BBA) - Bioenergetics 325(1):8193. doi:10.1016/0005-2728(73)90153-9

Amos BK, Daprato RC, Hughes JB, Pennell KD, Löffler FE (2007) Effects of the nonionic surfactant tween 80 on microbial reductive dechlorination of chlorinated ethenes. Environmental Science \& Technology 41(5):1710-1716. doi:10.1021/es061926v

Amos BK, Ritalahti KM, Cruz-Garcia C, Padilla-Crespo E, Löffler FE (2008) Oxygen effect on Dehalococcoides viability and biomarker quantification. Environmental Science \& Technology 42(15):5718 5726. doi:10.1021/es703227g

Amos BK, Suchomel EJ, Pennell KD, Löffler FE (2009) Spatial and temporal distributions of Geobacter lovleyi and Dehalococcoides spp. during bioenhanced PCE-NAPL dissolution. Environmental Science \& Technology 43(6):1977-1985. doi:10.1021/es8027692

Andersson O, Ekkestubbe J, Ekdahl A (2013) UTES (Underground Thermal Energy Storage) - applications and market development in Sweden. Journal of Energy and Power Engineering 7(4):669

Aulenta F, Majone M, Tandoi V (2006) Enhanced anaerobic bioremediation of chlorinated solvents: environmental factors influencing microbial activity and their relevance under field conditions. J Chem Technol Biotechnol 81(9):1463-1474. doi:10.1002/jctb.1567

Bénézeth P, Dandurand JL, Harrichoury JC (2009) Solubility product of siderite $\left(\mathrm{FeCO}_{3}\right)$ as a function of temperature $\left(25-250{ }^{\circ} \mathrm{C}\right)$. Chem Geol 265(1-2):3-12. doi:10.1016/j.chemgeo.2009.03.015

Ballapragada BS, Stensel HD, Puhakka JA, Ferguson JF (1997) Effect of hydrogen on reductive dechlorination of chlorinated ethenes. Environmental Science \& Technology 31(6):1728-1734. doi:10. 1021/es9606539

Bard AJ, Faulkner LR (2001) Electrochemical methods: fundamentals and applications, 2nd edn

Behrens S, Azizian MF, McMurdie PJ, Sabalowsky A, Dolan ME, Semprini L, Spormann AM (2008) Monitoring abundance and expression of "Dehalococcoides" species chloroethene-reductive dehalogenases in a tetrachloroethene-dechlorinating flow column. Appl Environ Microbiol 74(18):5695-5703. doi:10.1128/AEM. 00926-08

Bonte M, Röling WF, Zaura E, van der Wielen PW, Stuyfzand PJ, van Breukelen BM (2013) Impacts of shallow geothermal energy production on redox processes and microbial communities. Environmental Science \& Technology 47(24):14476-14484. doi: 10.1021/es4030244

Boopathy R (2000) Factors limiting bioremediation technologies. Bioresour Technol 74(1):63-67. doi:10.1016/S0960-8524(99) 00144-3

Božic A, Anderson R, Carstens G, Ricke S, Callaway T, Yokoyama M, Wang J, Nisbet D (2009) Effects of the methane-inhibitors nitrate, nitroethane, lauric acid, Lauricidin ${ }^{\circledR}$ and the Hawaiian marine algae Chaetoceros on ruminal fermentation in vitro. Bioresour Technol 100(17):4017-4025. doi:10.1016/j.biortech.2008.12.061

Brown CJ, Misut PE (2010) Aquifer geochemistry at potential aquifer storage and recovery sites in coastal plain aquifers in the New York city area, USA. Appl Geochem 25(9):1431-1452. doi:10.1016/j. apgeochem.2010.07.001

Brunet R, Garcia-Gil L (1996) Sulfide-induced dissimilatory nitrate reduction to ammonia in anaerobic freshwater sediments. FEMS Microbiol Ecol 21(2):131-138. doi:10.1111/j.1574-6941.1996. tb00340.x

Burston MW, Nazari MM, Bishop PK, Lerner DN (1993) Pollution of groundwater in the Coventry region (UK) by chlorinated hydrocarbon solvents. J Hydrol 149(1-4):137-161. doi:10.1016/00221694(93)90104-H

CBS (2010) Hernieuwbare energie in Nederland 2009 (renewable energy in the Netherlands 2009). Centraal bureau voor de statistiek, Den Haag/Heerlen

Chang B-V, Zheng J-X, Yuan S-Y (1996) Effects of alternative electron donors, acceptors and inhibitors on pentachlorophenol dechlorination in soil. Chemosphere 33(2):313-320. doi:10.1016/00456535(96)00174-9

Chen IM, Chang B-V, Yuan S-Y, Wang Y-S (2002) Reductive dechlorination of hexachlorobenzene under various additions. Water Air Soil Pollut 139(1-4):61-74. doi:10.1023/A:1015861217112

Christensen TH, Bjerg PL, Banwart SA, Jakobsen R, Heron G, Albrechtsen H-J (2000) Characterization of redox conditions in groundwater contaminant plumes. J Contam Hydrol 45(3-4):165241. doi:10.1016/S0169-7722(00)00109-1

Cupples AM, Spormann AM, McCarty PL (2003) Growth of a Dehalococcoides-like microorganism on vinyl chloride and cisdichloroethene as electron acceptors as determined by competitive PCR. Appl Environ Microbiol 69(2):953-959. doi:10.1128/aem.69. 2.953-959.2003

Cupples AM, Spormann AM, McCarty PL (2004) Vinyl chloride and cisdichloroethene dechlorination kinetics and microorganism growth under substrate limiting conditions. Environmental Science \& Technology 38(4):1102-1107. doi:10.1021/es0348647

Davison W (1980) A critical comparison of the measured solubilities of ferrous sulphide in natural waters. Geochim Cosmochim Acta 44(6): 803-808. doi:10.1016/0016-7037(80)90261-6

Doğan-Subașı E, Bastiaens L, Boon N, Dejonghe W (2013) Microbial dechlorination activity during and after chemical oxidant treatment. J Hazard Mater 262:598-605. doi:10.1016/j.jhazmat.2013.09.003

Doong R-a, Chen T-f, Wu Y-w (1997) Anaerobic dechlorination of carbon tetrachloride by free-living and attached bacteria under various electron-donor conditions. Appl Microbiol Biotechnol 47(3):317323. doi:10.1007/s002530050934

EC (2007) Limiting global climate change to 2 degrees Celsiusthe way ahead for 2020 and beyond. European Commission, Brussels

Elefsiniotis P, Wareham D, Smith M (2004) Use of volatile fatty acids from an acid-phase digester for denitrification. J Biotechnol 114(3): 289-297. doi:10.1016/j.jbiotec.2004.02.016

Fass S, Ganaye V, Urbain V, Manem J, Block J (1994) Volatile fatty acids as organic carbon sources in denitrification. Environ Technol 15(5): 459-467. doi:10.1080/09593339409385450 
Genthner BRS, Price WA, Pritchard PH (1989) Anaerobic degradation of chloroaromatic compounds in aquatic sediments under a variety of enrichment conditions. Appl Environ Microbiol 55(6):1466-1471

Gerritse J, Kloetstra G, Borger A, Dalstra G, Alphenaar A, Gottschal JC (1997) Complete degradation of tetrachloroethene in coupled anoxic and oxic chemostats. Appl Microbiol Biotechnol 48(4):553-562. doi: $10.1007 / \mathrm{s} 002530051096$

Giacobbe FW (1992) Oxygen permeation through Teflon-PFA tubing into flowing argon. J Appl Polym Sci 46(6):1113-1116. doi:10. 1002/app.1992.070460621

Godschalk MS, Bakema G (2009) 20,000 ATES systems in the Netherlands in 2020 - Major step towards a sustainable energy supply. Paper presented at the EFFSTOCK 2009 (11th International) Thermal Energy Storage for Efficiency and Sustainability, Stockholm,

Grindstaff M (1998) Bioremediation of chlorinated solvent contaminated groundwater. US Environmental Protection Agency, Office of Solid Waste and Emergency Response, Technology Innovation Office

Guerrero MG, Vega JM, Losada M (1981) The assimilatory nitratereducing system and its regulation. Annu Rev Plant Physiol 32(1): 169-204. doi:10.1146/annurev.pp.32.060181.001125

Häggblom MM, Rivera MD, Young LY (1993) Influence of alternative electron acceptors on the anaerobic biodegradability of chlorinated phenols and benzoic acids. Appl Environ Microbiol 59(4):11621167

He J, Holmes VF, Lee PKH, Alvarez-Cohen L (2007) Influence of vitamin B12 and cocultures on the growth of Dehalococcoides isolates in defined medium. Appl Environ Microbiol 73(9):2847-2853. doi: 10.1128/aem.02574-06

He J, Ritalahti KM, Yang K-L, Koenigsberg SS, Löffler FE (2003) Detoxification of vinyl chloride to ethene coupled to growth of an anaerobic bacterium. Nature 424(6944):62-65. doi:10.1038/ nature 01717

Hendriks M, Snijders A, Boido N (2008) Underground thermal energy storage for efficient heating and cooling of buildings. Paper presented at the 1st International Conference on Industrialised, Integrated, Intelligent Construction, Loughborough, UK,

Henry SM, Warner SD (2003) Chlorinated solvent and Dnapl remediation - innovative strategies for subsurface cleanup. Amer Chemical Soc, Washington

Houben GJ (2006) The influence of well hydraulics on the spatial distribution of well incrustations. Groundwater 44(5):668-675. doi:10. $1111 / j .1745-6584.2006 .00216 . x$

Hrapovic L, Sleep BE, Major DJ, Hood ED (2005) Laboratory study of treatment of trichloroethene by chemical oxidation followed by bioremediation. Environmental Science \& Technology 39(8):2888 2897. doi: $10.1021 / \mathrm{es} 049017 \mathrm{y}$

Hu M, Zhang Y, Liu Y, Wang X, Wong P-K (2013) Effect of different nutrients on the anaerobic degradation of trichloroethene at optimal temperature. International Biodeterioration \& Biodegradation 85: 103-107. doi:10.1016/j.ibiod.2013.06.008

ITRC (2005) Overview of in situ bioremediation of chlorinated ethene DNAPL source zones. Washington D.C.

ITRC (2008) Enhanced attenuation: chlorinated organics. Interstate Technology and Regulatory Council Washington D.C.

Jesußek A, Grandel S, Dahmke A (2013) Impacts of subsurface heat storage on aquifer hydrogeochemistry. Environmental Earth Sciences 69(6):1999-2012. doi:10.1007/s12665-012-2037-9

Keith PA, Lai CK, Kjeldsen P, Lo IC (2005) Effect of groundwater inorganics on the reductive dechlorination of TCE by zero-valent iron. Water Air Soil Pollut 162(1-4):401-420. doi:10.1007/s11270-0057420-7

Kohfahl C, Massmann G, Pekdeger A (2009) Sources of oxygen flux in groundwater during induced bank filtration at a site in Berlin, Germany. Hydrogeol J 17(3):571-578. doi:10.1007/s10040-0080389-8
Kouznetsova I, Mao XM, Robinson C, Barry DA, Gerhard JI, McCarty PL (2010) Biological reduction of chlorinated solvents: batch-scale geochemical modeling. Adv Water Resour 33(9):969-986. doi:10. 1016/j.advwatres.2010.04.017

Lee KS (2010) A review on concepts, applications, and models of aquifer thermal energy storage systems. Energies 3(6):1320-1334. doi:10. 3390/En3061320

Lee KS (2013) Aquifer thermal energy storage underground thermal energy storage. Springer, pp 59-93

Lendvay JM, Löffler FE, Dollhopf M, Aiello MR, Daniels G, Fathepure BZ, Gebhard M, Heine R, Helton R, Shi J, Krajmalnik-Brown R, Major CL, Barcelona MJ, Petrovskis E, Hickey R, Tiedje JM, Adriaens P (2003) Bioreactive barriers: a comparison of bioaugmentation and biostimulation for chlorinated solvent remediation. Environmental Science \& Technology 37(7):1422-1431. doi:10. 1021/es025985u

Lieten S, de Vries E, van Baaren E, Bakr M, Oude EG, Hartog N, Meinderstma W, van Nieuwkerk E, van Oostrom N, Woning M, Drijver B, Krajenbrink H, Mathijssen H, Wennekes R (2012) Literatuuronderzoek: Overzicht van kennis en onderzoeksvragen rondom bodemenergie. In: MMB (ed). Meer met Bodemenergie (MMB)

Linn W, Appel L, Davis G, DeZeeuw R, C. Dukes, Eriksen P, Farrell J, Fitton D, J.Gilbert, Haas J, Henning L, Jurgens R, Pyles B, Schmidt R, So J, Spencer A, Trippler D, Wilson P (2004) Conducting contamination assessment work at dry cleaning sites.. State Coalition for Remediation of Drycleaners.

Longstaff SL, Aldous PJ, Clark L, Flavin RJ, Partington J (1992) Contamination of the chalk aquifer by chlorinated solvents: a case study of the Luton and Dunstable area. Journal of the Institution of Water and Environmental Management 6(5):541-550. doi:10.1111/ j.1747-6593.1992.tb00789.x

Lopes TJ, Bender DA (1998) Nonpoint sources of volatile organic compounds in urban areas - relative importance of land surfaces and air. Environ Pollut 101(2):221-230. doi:10.1016/S0269-7491(98) 00048-7

Lu X, Wilson JT, Kampbell DH (2006) Relationship between Dehalococcoides DNA in ground water and rates of reductive dechlorination at field scale. Water Res 40(16):3131-3140. doi:10. 1016/j.watres.2006.05.030

Major DW, McMaster ML, Cox EE, Edwards EA, Dworatzek SM, Hendrickson ER, Starr MG, Payne JA, Buonamici LW (2002) Field demonstration of successful bioaugmentation to achieve dechlorination of tetrachloroethene to ethene. Environmental Science \& Technology 36(23):5106-5116. doi:10.1021/es0255711

Maymó-Gatell X, Nijenhuis I, Zinder SH (2001) Reductive dechlorination of cis-1, 2-dichloroethene and vinyl chloride by "Dehalococcoides ethenogenes". Environmental Science \& Technology 35(3):516-521. doi:10.1021/es001285i

McCarty PL (1997) Microbiology — breathing with chlorinated solvents. Science 276(5318):1521-1522. doi:10.1126/science.276.5318. 1521

McCarty PL (2010) Groundwater contamination by chlorinated solvents: History, remediation technologies and strategies In Situ Remediation of Chlorinated Solvent Plumes. Springer, pp 1-28

McMahon PB, Chapelle FH (2008) Redox processes and water quality of selected principal aquifer systems. Groundwater 46(2):259-271. doi:10.1111/j.1745-6584.2007.00385.x

Middeldorp PM, van Doesburg W, Schraa G, Stams AM (2005) Reductive dechlorination of hexachlorocyclohexane $(\mathrm{HCH})$ isomers in soil under anaerobic conditions. Biodegradation 16(3):283-290. doi:10.1007/s10532-004-1573-8

Milligan PW, Häggblom MM (1999) Biodegradation and biotransformation of dicamba under different reducing conditions. Environmental Science \& Technology 33(8):1224-1229. doi:10.1021/es981117e 
Miura T, Yamazoe A, Ito M, Ohji S, Hosoyama A, Takahata Y, Fujita N (2015) The impact of injections of different nutrients on the bacterial community and its dechlorination activity in chloroethenecontaminated groundwater. Microbes Environ 30(2):164-171. doi: 10.1264/jsme2.ME14127

Mohn WW, Tiedje JM (1992) Microbial reductive dehalogenation. Microbiol Rev 56(3):482-507

Moran MJ, Zogorski JS, Squillace PJ (2007) Chlorinated solvents in groundwater of the United States. Environmental Science \& Technology 41(1):74-81. doi:10.1021/es061553y

Nelson DK, Hozalski RM, Clapp LW, Semmens MJ, Novak PJ (2002) Effect of nitrate and sulfate on dechlorination by a mixed hydrogenfed culture. Bioremediation Journal 6(3):225-236. doi:10.1080/ 10889860290777585

Ni Z, Smit M, Grotenhuis T, van Gaans P, Rijnaarts H (2014) Effectiveness of stimulating PCE reductive dechlorination: a stepwise approach. J Contam Hydrol 164:209-218. doi:10.1016/j. jconhyd.2014.06.005

Ni Z, van Gaans P, Smit M, Rijnaarts H, Grotenhuis T (2015) Biodegradation of cis-1,2-dichloroethene in simulated underground thermal energy storage systems. Environmental Science \& Technology 49(22):13519-13527. doi:10.1021/acs.est.5b03068

Nobre RCM, Nobre MMM (2004) Natural attenuation of chlorinated organics in a shallow sand aquifer. J Hazard Mater 110(1-3):129 137. doi:10.1016/j.jhazmat.2004.02.046

Novo AV, Bayon JR, Castro-Fresno D, Rodriguez-Hernandez J (2010) Review of seasonal heat storage in large basins: water tanks and gravel-water pits. Appl Energy 87(2):390-397. doi:10.1016/j. apenergy.2009.06.033

Okutman Tas D, Pavlostathis SG (2008) Effect of nitrate reduction on the microbial reductive transformation of pentachloronitrobenzene. Environmental Science \& Technology 42(9):3234-3240. doi:10. 1021/es702261w

Paksoy H, Gürbüz Z, Turgut B, Dikici D, Evliya H (2004) Aquifer thermal storage (ATES) for air-conditioning of a supermarket in Turkey. Renew Energy 29(12):1991-1996. doi:10.1016/j.renene.2004.03. 007

Paksoy H, Snijders A, Stiles L (2009) Aquifer Thermal Energy Cold Storage System at Richard Stockton College. Paper presented at the EFFSTOCK 2009 (11th International)-Thermal Energy Storage for Efficiency and Sustainability, Stockholm,

Paksoy HÖ (2007) Thermal energy storage for sustainable energy consumption: fundamentals, case studies and design, vol 234 Springer Science \& Business Media

Parker LV, Hewitt AD, Jenkins TF (1990) Influence of casing materials on trace-level chemicals in well water. Groundwater Monitoring \& Remediation 10(2):146-156. doi:10.1111/j.1745-6592.1990. tb00346.x

Peirce EC (1958) Diffusion of oxygen and carbon dioxide through Teflon membranes. AMA Archives of Surgery 77(6):938-943

Picardal F, Arnold RG, Huey BB (1995) Effects of electron donor and acceptor conditions on reductive dehalogenation of tetrachloromethane by shewanella putrefaciens 200. Appl Environ Microbiol 61(1): $8-12$

Picone S (2012) Transport and biodegradation of volatile organic compounds: influence on vapor intrusion into buildings. Wageningen University, Dissertation

Possemiers M (2014) Aquifer thermal energy storage under different hydrochemical and hydrogeological conditions. University of Leuven, Dissertation

Possemiers M, Huysmans M, Batelaan O (2014) Influence of aquifer thermal energy storage on groundwater quality: a review illustrated by seven case studies from Belgium. Journal of Hydrology: Regional Studies 2(0):20-34. doi:10.1016/j.ejrh.2014.08.001

Postma D, Boesen C, Kristiansen H, Larsen F (1991) Nitrate reduction in an unconfined sandy aquifer: water chemistry, reduction processes, and geochemical modeling. Water Resour Res 27(8):2027-2045. doi:10.1029/91WR00989

Reinhold A, Westermann M, Seifert J, von Bergen M, Schubert T, Diekert G (2012) Impact of vitamin B 12 on formation of the tetrachloroethene reductive dehalogenase in Desulfitobacterium hafniense Strain Y51. Appl Environ Microbiol 78(22):8025-8032. doi:10.1128/aem.02173-12

Ritter K, Odziemkowski MS, Simpgraga R, Gillham RW, Irish DE (2003) An in situ study of the effect of nitrate on the reduction of trichloroethylene by granular iron. J Contam Hydrol 65(1-2):121-136. doi:10.1016/S0169-7722(02)00234-6

Rowe RK, Hrapovic L, Kosaric N (1995) Diffusion of chloride and dichloromethane through an HDPE geomembrane. Geosynth Int 2(3): 507-536. doi:10.1680/gein.2.0021

Roy R, Conrad R (1999) Effect of methanogenic precursors (acetate, hydrogen, propionate) on the suppression of methane production by nitrate in anoxic rice field soil. FEMS Microbiol Ecol 28(1): 49-61. doi:10.1111/j.1574-6941.1999.tb00560.x

Sahl JW, Munakata-Marr J, Crimi ML, Siegrist RL (2007) Coupling permanganate oxidation with microbial dechlorination of tetrachloroethene. Water Environment research 79(1):5-12. doi:10. 2175/106143006X136720

Sanner B, Kabus F, Seibt P, Bartels J (2005) Underground thermal energy storage for the German parliament in berlin, system concept and operational experience. Paper presented at the proceedings of world geothermal congress. Antalya, Turkey

Schaefer CE, Condee CW, Vainberg S, Steffan RJ (2009) Bioaugmentation for chlorinated ethenes using Dehalococcoides sp.: comparison between batch and column experiments. Chemosphere 75(2):141-148. doi:10.1016/j.chemosphere.2008.12. 041

Scheutz C, Nd D, Dennis P, Hansen MH, Jørgensen T, Jakobsen R, Ee C, Bjerg PL (2008) Concurrent ethene generation and growth of Dehalococcoides containing vinyl chloride reductive dehalogenase genes during an enhanced reductive dechlorination field demonstration. Environmental Science \& Technology 42(24):9302-9309. doi: 10.1021/es $800764 \mathrm{t}$

Schlicker O, Ebert M, Fruth M, Weidner M, Wüst W, Dahmke A (2000) Degradation of TCE with iron: the role of competing chromate and nitrate reduction. Groundwater 38(3):403-409. doi:10.1111/j.17456584.2000.tb00226.x

Seeliger S, Janssen PH, Schink B (2002) Energetics and kinetics of lactate fermentation to acetate and propionate via methylmalonyl-CoA or acrylyl-CoA. FEMS Microbiol Lett 211(1):65-70. doi:10.1016/ S0378-1097(02)00651-1

Semprini L, Hopkins GD, McCarty PL, Roberts PV (1992) In-situ transformation of carbon tetrachloride and other halogenated compounds resulting from biostimulation under anoxic conditions. Environmental Science \& Technology 26(12):2454-2461. doi:10. 1021/es00036a018

Slenders HLA, Dols P, Verburg R, de Vries AJ (2010) Sustainable remediation panel: sustainable synergies for the subsurface: combining groundwater energy with remediation. Remediation 20(2):143-153. doi:10.1002/rem.20246

Smidt H, de Vos WM (2004) Anaerobic microbial dehalogenation. Annu Rev Microbiol 58:43-73. doi:10.1146/annurev.micro.58.030603. 123600

Snijders A (2005) Aquifer thermal energy storage in the Netherlands status beginning of 2005. IFTech International BV, Arnhem

Sommer W (2015) Modelling and monitoring of aquifer thermal energy storage: impacts of soil heterogeneity, thermal interference and bioremediation. Wageningen University, Dissertation

Sommer W, Valstar J, Leusbrock I, Grotenhuis T, Rijnaarts H (2015) Optimization and spatial pattern of large-scale aquifer thermal energy storage. Appl Energy 137:322-337. doi:10.1016/j.apenergy. 2014.10.019 
Squillace PJ, Scott JC, Moran MJ, Nolan BT, Kolpin DW (2002) VOCs, pesticides, nitrate, and their mixtures in groundwater used for drinking water in the United States. Environmental Science \& Technology 36(9):1923-1930. doi:10.1021/es015591n

Stirling A (2011) $\mathrm{HCO}_{3}{ }^{-}$formation from $\mathrm{CO}_{2}$ at high $\mathrm{pH}$ : ab initio molecular dynamics study. J Phys Chem B 115(49):14683-14687. doi: 10.1021/jp2084204

Straub KL, Benz M, Schink B, Widdel F (1996) Anaerobic, nitratedependent microbial oxidation of ferrous iron. Appl Environ Microbiol 62(4):1458-1460

Sutton NB, Atashgahi S, van der Wal J, Wijn G, Grotenhuis T, Smidt H, Rijnaarts HHM (2015) Microbial dynamics during and after in situ chemical oxidation of chlorinated solvents. Groundwater 53(2): 261-270. doi:10.1111/gwat.12209

Theis TL, Singer PC (1974) Complexation of iron(II) by organic matter and its effect on iron(II) oxygenation. Environmental Science \& Technology 8(6):569-573. doi:10.1021/es60091a008

van Beek C (2011) Cause and prevention of clogging of wells abstracting groundwater from unconsolidated aquifers. Dissertation, VU Amsterdam

van der Zaan B, Hannes F, Hoekstra N, Rijnaarts H, de Vos WM, Smidt H, Gerritse J (2010) Correlation of Dehalococcoides 16S rRNA and chloroethene-reductive dehalogenase genes with geochemical conditions in chloroethene-contaminated groundwater. Appl Environ Microbiol 76(3):843-850. doi:10.1128/aem.01482-09

Vanhoudt D, Desmedt J, Van Bael J, Robeyn N, Hoes H (2011) An aquifer thermal storage system in a Belgian hospital: long-term experimental evaluation of energy and cost savings. Energy and Buildings 43:3657-3665. doi:10.1016/j.enbuild.2011.09.040

Verburg R, Slenders H, Hoekstra N, van Nieuwkerk E, Guijt R, van der Mark B, Mimpen J (2010) Handleiding BOEG - Bodemenergie en Grondwaterverontreiniging, het ijs is gebroken. Nederlandse Vereniging voor Ondergrondse Energieopslagsystemen, Den Bosch

Wilson K, Sewell G, Kean JA, Vangelas K (2007) Enhanced attenuation: its place in the remediation of chlorinated solvents. Remediation 17(2):39-49. doi:10.1002/rem.20123

Wu J, H-m Z, H-z L, P-c Z, Jiang J (2009) Impacts of hydrodynamic shear force on nucleation of flocculent sludge in anaerobic reactor. Water Res 43(12):3029-3036. doi:10.1016/j.watres.2009.04.026

Zuurbier KG, Hartog N, Valstar J, Post VEA, van Breukelen BM (2013) The impact of low-temperature seasonal aquifer thermal energy storage (SATES) systems on chlorinated solvent contaminated groundwater: modeling of spreading and degradation. J Contam Hydrol 147(0):1-13. doi:10.1016/j.jconhyd.2013.01.002 